On the steamship expeditions sent out by the Canadian Government to Hudson Strait and Bay, Dr. Bell not only acted as geologist and naturalist, but on the Neptune and Alert expeditions as medical officer as well.

The above is only a brief outline of the places Dr. Bell has visited and the work he has done, for no mention has been made of the time he has spent at the Great Slave Lake. This lake is 300 miles long and is a distance of 3000 miles from Ottawa, so no small journey! For the past few years, however, it has been possible to go a great part of the way by train and steamer. Here attention may be drawn to the fact that the work on the prairies and plains was accomplished before any treaties had been made with the Indians, and before the organisation of the mounted police. In those days, that part of the country was scarcely, if at all, settled, except further north, where it was practically only known to the Hudson's Bay Company's people. The buffalo was very plentiful then, and it may be surmised that the adventures of Dr. Bell were many and exciting. Taking into account all the discomfort from exposure and fatigue, the want of food, and the usual hardships connected with exploring, we may safely say that in the forty-four years of Dr. Bell's annual expeditions, he has had more adventures, more experiences of every description, and seen more of the fauna and flora of North America than any other white man living, besides having been brought into close contact with the real wild Indians, the Eskimos and the Hudson's Bay Company's people, and thus getting a thorough insight into their manners and customs.

During this time not only has he made geological, geographical and topographical surveys, but has collected a great quantity of zoological and botanical specimens, taken many photographs of these far-away parts, and made observations in a great many varied directions, greatly interesting himself in the folk-lore of the Indian tribes and the Eskimos. Dr. Bell has been called by Mr. George Johnson, the official Dominion Statistician, "the place-name father of Canada," for as his work has been so much in unknown parts he has had to give a great number of names.

In spite of the exposure and hardships he has had to experience, Dr. Bell is in perfect health and as keen and untiring about work as ever. He attributes his health to the care he has always taken of himself when camping out, always endeavouring to have a dry comfortable bed of brush or some substitute every night, trying to be as short a time as possible in wet clothes and missing as few meals as he could. It has been his habit to "live of the country and to go light," therefore he never carried any camp equipments. His food was of the simplest, being the same as that of the voyageur, with fish and game when it was to be had and with no alcoholic drinks.

Dr. Bell is of a very quiet and retiring disposition and has kept himself so much in the background that few know of the vast extent of his work. He has been the means of immense areas being mapped and divided into territories and provinces, and when we try to realise the greatness of Canada, the sizes of the rivers, lakes and plains which have been surveyed by him, the extent of land which this one man has journeyed over, we are amazed at the greatness of the work accomplished. He has published about 190 reports on various scientific subjects, but, except for short accounts like that written by $\mathrm{Mr}$. Hallock, no record has been published of all his explorations, for, although often asked, Dr. Bell has never given a detailed account of his travels or attempted to extend and publish his own notes, probably owing to pressure of work and his natural reticence.

We are very grateful to Mr. Hallock for giving us an insight into what Dr. Bell has done, and wish Dr. Bell much success in his position as director of the Canadian Geological Survey.

$$
\text { NO. I } 647 \text {, vOL. } 64]
$$

\section{SIR COURTENAY BOYLE, K.C.B.}

$\mathrm{BY}$ the death of Sir Courtenay Boyle, K.C.B., which took place very suddenly on Sunday last, the country has lost a distinguished public servant and science a very warm friend and powerful supporter.

He was born in 1845 , and educated at Charterhouse and Christ Church. At Oxford he became a noted cricketer, playing for the University from 1865 to 1867. In 1868 he began his official life as private secretary to Lord Spencer, then Viceroy of Ireland, an office which he held a second time from I 868-1873. After serving for twelve years as a Local Government Board inspector, in I 886 he entered the Board of Trade as assistant secretary in the Railway Department, in succession to Sir H. Calcraft, who had become permanent secretary to the Board. In 1893, when Sir H. Calcraft retired, Sir Courtenay Boyle, who a year previously had been made K.C.B., succeeded him as permanent secretary. For the past fifteen years he was intimately connected with legislation of the most important character. As assistant secretary he was responsible, along with Lord Balfour, for revising the rates and charges of the railway companies of the United Kingdom. The consolidation of the statutes relating to merchant shipping was his work, and he had much to do with the Conciliation Act of 1896.

But it was in connection with legislation to regulate the supply of electricity for light and power that he was first brought closely into relation with physical science. The position of the electric industries has changed enormously since I886; earlier legislation had, in many respects, been hostile to their growth. Sir Courtenay's efforts were all in favour of progress, and even those who think that in some respects the progress might have been greater will admit that the difficulties to be overcome were considerable, and that the permanent secretary was always ready to give any reasonable suggestion a fair and courteous consideration. Those who in I $890-9$ I served with him on the committee which formulated the legal definitions of the ohm, the ampere and the volt, can testify to his care and skill; he was excellent in the chair, possibly in consequence of the fact that he made no claim to be considered an expert on the subject under discussion, but brought a trained business intellect to bear on the problem of putting into a practical form the results of scientific inquiries.

Nor were his sympathies confined to the applications of science. In the recent somewhat acute controversies respecting the magnetic observatories and electric traction, he made it clear to all that he appreciated the importance of a scientific investigation which for the present does not promise direct practical applications ; and the satisfactory solution of the difficulty is due in great measure to his tact and patience.

His connection with the National Physical Laboratory was most close and intimate. He was a member of Lord Rayleigh's Committee, and took part in the discussions which led up to the foundation of the Laboratory. As permanent secretary of the Board of Trade he was an ex-officio member of the General Board and Executive Committee; he also served on the Finance Committee and various subcommittees, and at all of these he was a most regular and useful attendant. In Lord Rayleigh's absence he usually acted as chairman, and in that position showed a very thorough grasp of the details of the work.

In the difficult discussions which arose as to the site of the Laboratory, his counsel and support were of the highest value; he gave his time freely to the work he had undertaken, and was always ready to discuss fully with the officers of the Royal Society, or the director, the proper course to follow.

He had formed high hopes of the position which the 
Laboratory might take and of its future progress, and he had it in his power greatly to help the realisation of those hopes. His death is a serious blow to the new institution-a blow the consequences of which can with difficulty be repaired.

R. T. G.

THE NATIONAL ANTARCTIC EXPEDITION.

$W^{E}$ print below a letter which Prof. Poulton has addressed to the Fellows of the Royal Society in regard to the Antarctic expedition. In it he gives a his. tory of the circumstances which have caused Prof. J. W. Gregory to resign the leadership of the scientific staff. The reason for this, to follow the Professor's words, is that since he left England in February changes have been made in his position in regard to the naval commander of the expedition which deprived him of any guarantee that the scientific work would not be subordinated to naval adventure, "an object admirable in itself, but not the one for which I understood this expedition to be organised." The history of the negotiations before and since the beginning of the present year-the date of the letter in which these words occur-show that when Prof. Gregory accepted the leadership of the scientific work (late in 1899), much stress had been laid on the scientific aspect of the expedition, and that the alterations made since the beginning of the present year have increased the authority of the naval commander.

At a special meeting of the Royal Society in February I898, when the advantages of an Antarctic expedition were fully discussed, Sir John Murray, in an admirable summary of matters requiring further study, enumerated not only the depth, the deposits and the biology of the South Polar Ocean, but also the meteorology, magnetism, geology, and ice-sheet of the region; and laid special stress on the importance of landing a party to remain over at least one winter in order to study the latter points. Dr. Neumayer, Sir Joseph Hooker, Sir A. Geikie and the Duke of Argyll all enlarged on the importance of one or more of the second group. The same were mentioned by members of the deputation, which Mr. Balfour received in June 1899 , and in his reply he acknowledged their importance. It is, therefore, not surprising that Prof. Gregory expected the leader of the scientific staff to be allowed a very free hand, and it certainly seems that the negotiations, described by Prof. Poulton, have tended to deprive him of initiative and to place him more completely under the authority of the naval commander. Yet this expedition will afford a great opportunity not only for geographical discovery, but also for increasing scientific knowledge; and for some most important things in the latter a prolonged stay on land is absolutely necessary. Chief among these, in addition to magnetic work, are the following:-The Antarctic land is covered by an ice-sheet greater than that of Greenland, and certainly not less than even the one which some glacialists assert to have formerly existed in Northern Europe. In that land also, as in no other place, we have a chance of obtaining the key to some curious problems in the zoology and botany, past and present, of other continental masses in the southern hemisphere. For both these problems a prolonged residence is required, and an expert who, like Prof. Gregory, is as familiar with ice and its work as he is with palæontological questions.

We may hope then that those representatives of science on the Joint Antarctic Committee whom Prof. Poulton accuses will be able to demonstrate that he is wrong and Prof. Gregory needlessly apprehensive, that Commander Scott possesses such experience in Polar exploration and has such familiarity with the branches of science which we have mentioned as to warrant a man of Prof. Gregory's age and standing in placing himself absolutely under his orders, and that the Discovery is a

$$
\text { NO. I } 647 \text {, VOL. 64] }
$$

King's ship in so full and real a sense that such entire subjection, even to signing articles, is imperative. Until their explanation is before us we cannot be expected to express a final opinion on the merits of the dispute, and this we shall no doubt obtain very shortly; for those whom Prof. Poulton has accused of running the risk of subordinating scientific investigation to geographical discovery can hardly afford to let judgment go by default.

$$
\text { To the Fellows of the Royal Society. }
$$

THE resignation of the man who is, before all others, fitted to be the Scientific Leader of the National Antarctic Expedition will lead the Fellows of the Society to expect some statement of the causes which have produced a result so disastrous to the interests of science. The following statement gives an account of the efforts which have been made to prevent the injury which has occurred.

In the autumn of I 899 Captain Tizard, F.R.S., and I were appointed as the representatives of the Council of the Royal Society on an Antarctic Executive Committee of four, Sir Clements Markham (Chairman) and Sir R. Vesey Hamilton being the representatives of the Royal Geographical Society's Council. Our functions were defined under various heads in a printed form previously agreed upon. No. 2 instructed us to submit a programme of the Expedition for approval to the Joint Antarctic Committee (consisting of sixteen representatives of each Council), "such a programme to include $(a)$ A general plan of the opera. tions of the Expedition, including instructions to the Commander, so far as this can be laid down beforehand. (b) The composition of the executive and scientific staff to be employed, the duties, preparation and accommodation for, and pay of, the several members." No. 4 instructed us "To make the appointments of the several members of the executive and scientific staff, subject to the final approval of the Joint Committee." The word "civilian" was nowhere employed. The four members of the Executive Committee were placed on the Joint Committee and all Sub-Committees.

Before the first meeting of the Executive Committee Captain Tizard and I were seen by Prof. Ruicker, who informed us that one of the first points which the Council of the Royal Society desired us to raise was the relation in power and status between the Commander and the Scientific Leader. In the German Expedition, which was to start about the same time, the Scientific Director had absolute power, and we were asked to consider the possibility of such an arrangement in the English Expedition.

At one of our first meetings, I think the very first, I raised this question and supported the German arrangement. The other three members, who were all naval experts, convinced me that English law required the Captain to be supreme in all questions relating to the safety of his ship and crew. Since that time 1 have never disputed this point, but always maintained that the scientific chief should be head of the scientific work of all kinds, including the geographical, and that the captain should be instructed to carry out his wishes so far as they were consistent with the safety of ship and crew.

We then considered the appointment of Scientific Leader and decided to nominate Prof J. W. Gregory, then of the British Museum of Natural History. In suggesting his name to my colleagues I was influenced by his proved success in organisation and in the management of men in a most difficult expedition. (British East Africa in 1893), by the wide grasp of science which enabled him to bring back valuable observations and collections in so many departments. His ice experience in Spitzbergen and Alpine regions was also of the highest importance, together with the fact that his chief subject was Geology, a science which pursued in the Antarctic Continent would almost certainly yield results of especial significance. In addition to all these qualifications Prof. Gregory's wide and varied knowledge of the earth rendered his opinion as to the lines of work which would be most likely to lead to marked success extremely valuable in such an Expedition. No one was more competent to state the probable structure of the Antarctic Continent and its relation to that of the earth. This opinion of Prof. Gregory's qualifications for the position of scientific leader of an Antarctic expedition is I know widely held among British scientific men. In their wide combination and united as they are to tried capacity as a leader they are unique, and an expedition with Prof. Gregory for its scientific chief, with as free a hand as English law would permit, was bound to yield great results. 